\title{
PENGUKURAN DAN ANALISIS HAMBUR BALIK AKUSTIK MENGGUNAKAN TEKNOLOGI MULTIBEAM ECHOSOUNDERUNTUK KLASIFIKASI SEDIMEN DASAR LAUT TELUK PALU
}

\section{MEASUREMENT AND ANALYSIS OF ACOUSTIC BACKSCATTER USING MULTIBEAM ECHOSOUNDER TECHNOLOGY FOR SEDIMENT CLASSIFICATION OF THE GULF OF PALU}

\author{
Rizqi Ayu Farihah ${ }^{1}$, Henry Munandar Manik ${ }^{2 *}$, \& Gentio Harsono ${ }^{3}$ \\ ${ }^{1}$ Program Studi Teknologi Kelautan, Sekolah Pascasarjana, IPB University, Bogor, 16680, Indonesia \\ ${ }^{2}$ Departemen Ilmu dan Teknologi Kelautan, FPIK, IPB University, Bogor, 16680, Indonesia \\ ${ }^{3}$ Pusat Hidrografi dan Oseanografi TNI-AL (PUSHIDROSAL), Jakarta, 14310, Indonesia \\ *E-mail: henrymanik@apps.ipb.ac.id
}

\begin{abstract}
Backscattering can describe sediments' condition in the bottom waters, including the grain size of the bottom waters sediments. This study aims to detect, classify, and estimate the bottom watershed based on backscattering values using Angular Responsse Analysis (ARA) and Support Vector Machine (SVM) so that a spatial map of sediment distribution is obtained in Gulf of Palu. Bathymetry data and backscattering intensity were taken on 5-9 October 2018 using the multibeam echosounder Kongsberg EM 302 with a frequency of $30 \mathrm{kHz}$, and ten sediment samples in 2012 belong to PUSHIDROSAL. The sediment distribution from the Gulf of Palu with the ARA method is dominated by sand and silt. Simultaneously, the distribution of sediments using the SVM method is dominated by silty sand, silt, and sand. Accuracy test results for the ARA methods produce an overall accuracy with a value of 50\%. In comparison, Accuracy test results for the SVM method produce an overall accuracy with a value of 60\%. The prediction of the basic types of waters in Palu Bay that are most close to the actual state is the prediction results using the SVM method, namely silt, silt, and sand.
\end{abstract}

Keywords: backscatter, multibeam echosounder, Palu gulf, sediment type, SVM

\begin{abstract}
ABSTRAK
Nilai Hambur balik dapat menggambarkan kondisi sedimen di dasar perairan, termasuk ukuran butir dari sedimen dasar perairan. Tujuan penelitian ini untuk mendeteksi, mengklasifikasi dan memprediksi tipe dasar perairan berdasarkan nilai hambur balik menggunakan Angular Responsse Analysis (ARA) dan Support Vector Machine (SVM) sehingga didapatkan peta spasial sebaran sedimen di Teluk Palu. Data batimetri dan intensitas hambur balik diambil pada 5-9 Oktober 2018 menggunakan multibeam echosounder Kongsberg EM 302 dengan frekuensi $30 \mathrm{kHz}$ dan 10 sampel sedimen tahun 2012 milik PUSHIDROSAL. Hasil penelitian menunjukkan sebaran sedimen dasar Teluk Palu dengan metode ARA didominasi oleh pasir (sand) dan lanau (silt) sedangkan dengan metode SVM didominasi oleh pasir berlanau (silty sand), lanau (silt) dan pasir (sand). Hasil uji akurasi untuk metode ARA sebesar $50 \%$ sedangkan hasil uji akurasi untuk metode SVM menghasilkan overall accuracy dengan nilai $60 \%$. Prediksi tipe dasar perairan di Teluk Palu yang paling mendekati keadaan sebenarnya adalah hasil prediksi dengan metode SVM yaitu pasir berlanau, lanau dan pasir.
\end{abstract}

Kata kunci: hambur balik, multibeam echosounder, SVM, tipe sedimen, Teluk Palu

\section{PENDAHULUAN}

Pemetaan dasar laut menggunakan multibeam echosounder dapat memberi gambaran yang sangat baik mengenai kolom maupun dasar perairan dengan akurasi yang tinggi (Manik, 2016). Hal ini sesuai dengan pendapat Hasan et al. (2014) bahwa multibeam merupakan alat yang sangat cocok untuk memetakan dasar perairan karena 
memiliki tingkat tutupan yang luas, resolusi hasil data yang tinggi dan memiliki cakupan kedalaman yang tinggi. Pemetaan dasar perairan sendiri penting dilakukan untuk mengetahui tipe sedimen dasar pada setiap perairan, dikarenakan setiap perairan memiliki karakteristik yang berbeda (Park et al., 2011). Multibeam echosounder menghasilkan dua tipe dataset yaitu data batimetri dan hambur balik (backscatter) yang sangat berguna untuk memetakan dasar perairan (Adi et al., 2016).

Nilai hambur balik dasar perairan dipengaruhi oleh sudut orientasi target, tingkat kekasaran dan kekerasan dari sedimen dasar (Manik, 2012). Substrat yang halus seperti lanau memiliki nilai hambur balik yang lebih kecil jika dibandingkan dengan nilai hambur balik pada sedimen dengan tingkat kekasaran yang lebih tinggi (Rzhanov et al., 2012), selain itu Manik (2012) juga menyatakan bahwa hambur balik dasar perairan dapat merepresentasikan tipe sedimen, ukuran butir, porositas dan tingkat kekasaran dasar perairan. Nilai hambur balik dari multibeam menunjukkan intensitas hamburan gelombang akustik dari dasar perairan yang digambarkan lewat grayscale, dimana dasar perairan yang berbeda akan memberikan nilai intensitas yang bervariasi (Hasan et al., 2014). Intensitas hambur balik ini yang banyak digunakan di berbagai teknik klasifikasi (Hasan et al., 2014), salah satunya adalah pengklasifikasian menggunakan Angular Responsse Analysis (ARA). Perangkat lunak Caris 8.1 merupakan salah satu perangkat lunak yang menggunakan ARA sebagai dasar algoritma dalam penentuan jenis sedimen dari intensitas hambur balik multibeam echosounder.

Support Vector Machine (SVM) merupakan teknik yang digunakan sebagai alat untuk klasifikasi suatu objek untuk mengenali pola dan memisahkannya ke dalam dua kelompok pola yang berbeda (Robotham et al., 2010). SVM dan Artificial Neural Network (ANN) merupakan satu alat klasifikasi objek yang banyak digunakan, diketahui bahwa SVM lebih efektif digunakan dibandingkan dengan ANN dalam membedakan suatu jenis objek (Robotham et al., 2010). Pada penelitian sebelumnya digunakan klasifikasi fuzzy logic dan ANN, penulis ingin mencoba menggunakan metode SVM yang merupakan metode supervised classification pada Machine Learning (Ludtke et al., 2012) untuk klasifikasi tipe dasar perairan. Perbandingan hasil klasifikasi antara metode ARA serta metode SVM perlu dilakukan, untuk melihat apakah metode SVM mampu mengklasifikasi dasar perairan berdasarkan intensitas hambur balik akustik.

Wilayah perairan yang akan digunakan sebagai studi kasus adalah wilayah sekitar Teluk Palu, Sulawesi Tengah. Wilayah ini dipilih karena beberapa pertimbangan, salah satunya karena adanya wilayah pelabuhan penting yaitu Pelabuhan Pantoloan yang merupakan Pelabuhan Internasional (Nasril, 2013) dan wilayah ini baru mengalami tsunami. Tsunami yang terjadi di Teluk Palu selain disebabkan oleh gempa juga dipengaruhi oleh adanya beberapa titik longsor bawah laut yang menjadi sumber lain tsunami (Gusman et al., 2019), sehingga menarik untuk dilakukan studi pasca tsunami terkait dasar perairan dan tipe sedimen yang ada di sekitar Teluk Palu.

Penggunaan data batimetri hasil multibeam echosounder sudah banyak dimanfaatkan untuk pemetaan dasar perairan, akan tetapi intensitas hambur balik yang merupakan hasil lain dari survei multibeam echosounder kurang dimanfaatkan, padahal intensitas hambur balik ini dapat digunakan untuk klasifikasi sedimen dasar perairan dan dapat digunakan sebagai gambaran awal sebaran sedimen dasar di suatu perairan khususnya Teluk Palu. Intensitas hambur balik dapat diolah dan di klasifikasi menggunakan ARA sehingga didapatkan rentang nilai hambur balik untuk jenis sedimen tertentu. Hasil klasifikasi data hambur balik dengan menggunakan ARA kemudian dibandingkan dengan sampel sedimen Teluk Palu yang telah dianalisis di 
laboratorium. Tujuan penelitian ini adalah mengklasifikasi tipe dasar perairan dari data hambur balik dan sedimen sehingga didapatkan peta spasial sebaran sedimen di Teluk Palu.

\section{METODE PENELITIAN}

Penelitian ini menggunakan instrumen multibeam echosounder yang dilaksanakan pada tanggal 5-9 Oktober 2018. Lokasi penelitian di Teluk Palu, Sulawesi
Tengah. Lajur pemeruman pada penelitian dapat dilihat pada Figure 1 dan titik pengambilan sampel sedimen menggunakan data tahun 2012 yang terdiri dari 10 titik.

Spesifikasi pada saat pemeruman dilakukan, dijelaskan pada laporan hasil penelitian milik PUSHIDROSAL dengan rincian kapal survei yang digunakan untuk penelitian adalah KRI Spica 932 yang memiliki panjang $60 \mathrm{~m}$ dengan tenaga 2 mesin diesel 8V 4000 M53 untuk 2 propeller. Kapal tersebut dapat melaju hingga kece-

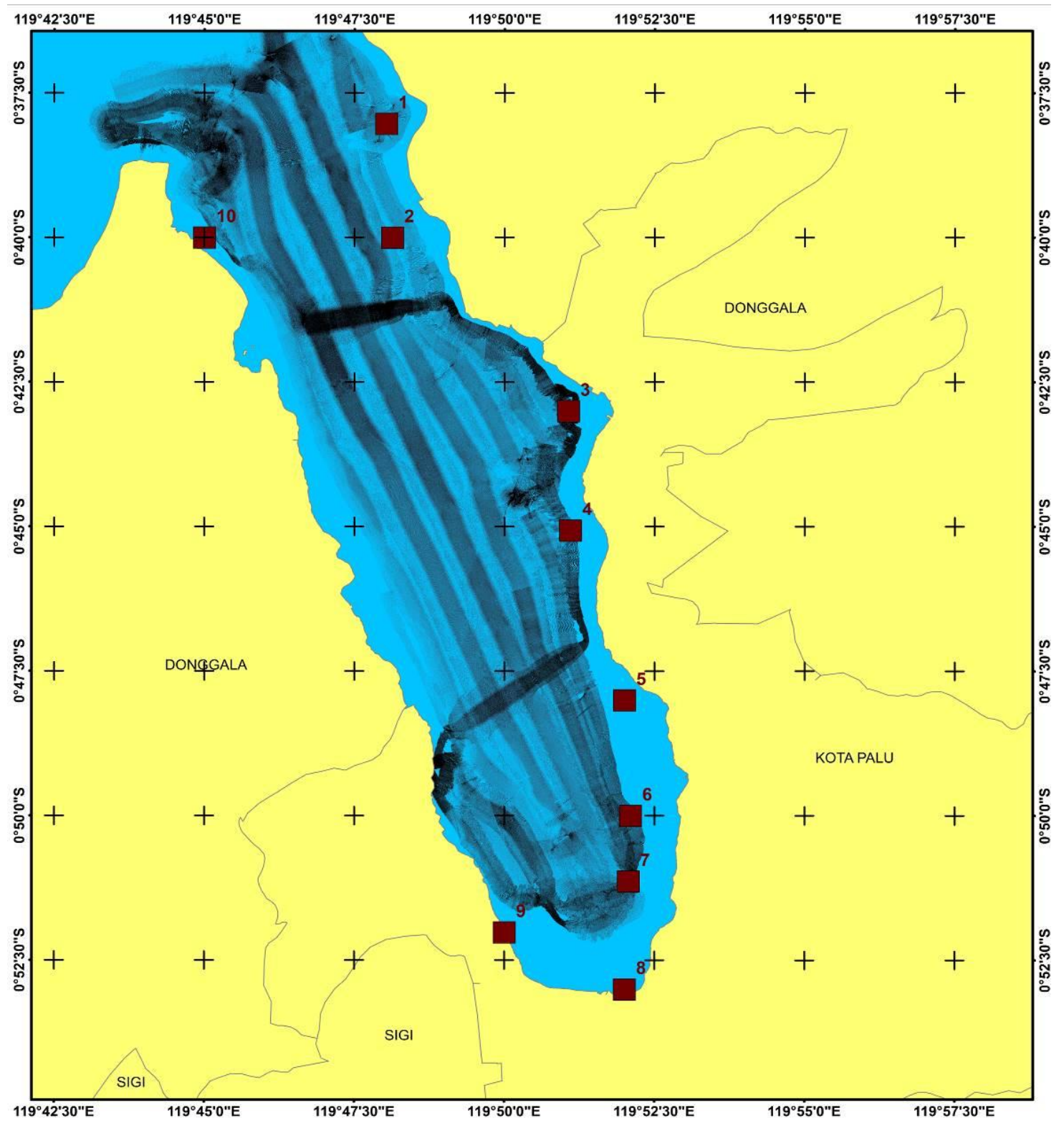

Figure 1. The sounding lane and the sediment sample points in the multibeam survey. 
patan maksimum 14 knot, jarak jelajahnya mencapai 4.400 nautical mile pada kecepatan 12 knot. Pemeruman menggunakan multibeam echosounder Kongsberg EM302 dengan frekuensi $30 \mathrm{kHz}$, kecepatan rata-rata perahu perum adalah 4 knot $(2,05 \mathrm{~m} / \mathrm{s})$ sampai dengan 6 knot $(3,1 \mathrm{~m} / \mathrm{s})$, lajur pemeruman memiliki jarak antar lajur sebesar 150 m. Kalibrasi kedalaman pada multibeam echosounder dilaksanakan setiap hari.

Pengolahan data berupa nilai hambur balik dan sampel sedimen dilakukan di Laboratorium Dishidro Pusat HidroOseanografi TNI Angkatan Laut yang berlokasi di Ancol, Jakarta Utara dan Laboratorium Akustik Kelautan dan Sistem Sonar, Departemen Ilmu dan Teknologi Kelautan, Fakultas Perikanan dan Ilmu Kelautan, Institut Pertanian Bogor. Data batimetri, hambur balik dan sampel sedimen di Teluk Palu, Sulawesi Tengah yang digunakan dalam penelitian ini merupakan data dari Pusat Hidro-Oseanografi (PUSHIDROS) TNI-AL. Data hasil survei yang digunakan dalam penelitian ini meliputi data batimetri, hambur balik dan data sampel sedimen dasar laut di Teluk Palu, Sulawesi Tengah.

\subsection{Pengolahan Data Batimetri}

Data batimetri merupakan salah satu data yang diperoleh dari multibeam echosounder. Data ini diolah menggunakan Caris Hips and Sips 8.1 proses pengolahan data dapat dilihat pada Figure 2.

Nilai hambur balik dalam bentuk raw data dan sudah dilakukan beberapa koreksi (Debese et al., 2012), diantaranya adalah koreksi dengan memasukan data kecepatan suara saat pemeruman dan data terkait kapal (arah kapal dll.) dapat digunakan untuk mengestimasi nilai kedalaman yang aktual (Hasan et al., 2014). Pengolahan data hambur balik dapat dilakukan setelah proses CUBE selesai dilakukan, sehingga data hambur balik yang diperoleh menggunakan data yang sudah terkoreksi dengan baik (MacDonald \& Collins, 2008).

\subsection{Pengolahan Data Hambur Balik Metode ARA}

Pengolahan hambur balik menggunakan algoritma geocoder yang dikembangkan oleh Fonseca sebagai penyempurna dari algoritma geocoder tersebut yang dikembangkan oleh Fonseca \& Mayer (Schnare, 2014). GeoBar merupakan gambar hasil hambur balik yang sudah terkoreksi georeference berbasis raster, beberapa geobar yang sudah terbentuk di overlay ke dalam satu layer membentuk mozaik backscatter (Fonseca \& Mayer, 2007).

Masing-masing beam memiliki sudut dimana pegaruhnya sangat besar terhadap nilai hambur balik yang diterima (Fonseca et al., 2009). ARA dapat menunjukkan impedansi akustik, kekasaran dan ukuran butir sedimen di area dekat dengan dasar laut berdasarkan dari sudut orientasi target. Proses pengolahan data hambur balik dapat dilihat pada Figure 3.

\subsection{Pengolahan Data Hambur Balik Metode SVM}

Tahun 1992 pertama diperkenalkan sistem SVM oleh Vapnik, idenya adalah untuk mencari hyperplane terbaik dengan memaksimalkan margin dan meminimalisir error yang terjadi (Bishop, 2006), sehingga SVM dapat memberikan solusi global yang optimal (Vapnik, 1995). SVM pada dasarnya merupakan sistem klasifikasi linier, kemudian dikembangkan dengan metode kernel trick (Bishop, 2006) dengan mengubah dataset ke dalam feature space dengan menggunakan fungsi kernel agar dapat digunakan pada klasifikasi non linier.

Prinsip klasifikasi SVM adalah dengan cara mencari fungsi pemisah (hyperplane) terbaik (Mandal et al., 2012), yaitu mengambil satu fungsi yang memiliki jarak yang secara maksimal dapat memisahkan dua kelas objek (Shahua, 2008). Proses pengolahan SVM pada perangkat lunak Python 3.8.2 (Figure 4).

Pengolahan data hambur balik dengan menggunakan SVM dikerjakan pada perang- 


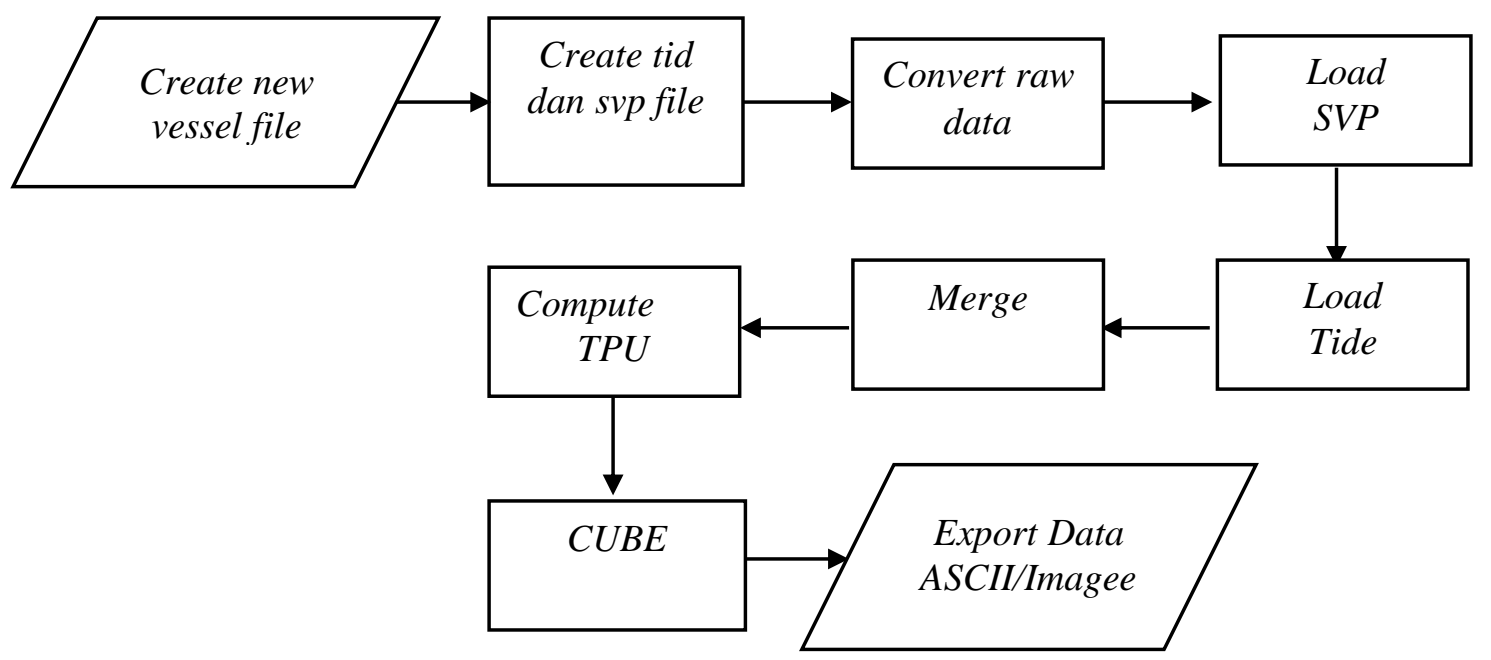

Figure 2. The bathymetry data processing.

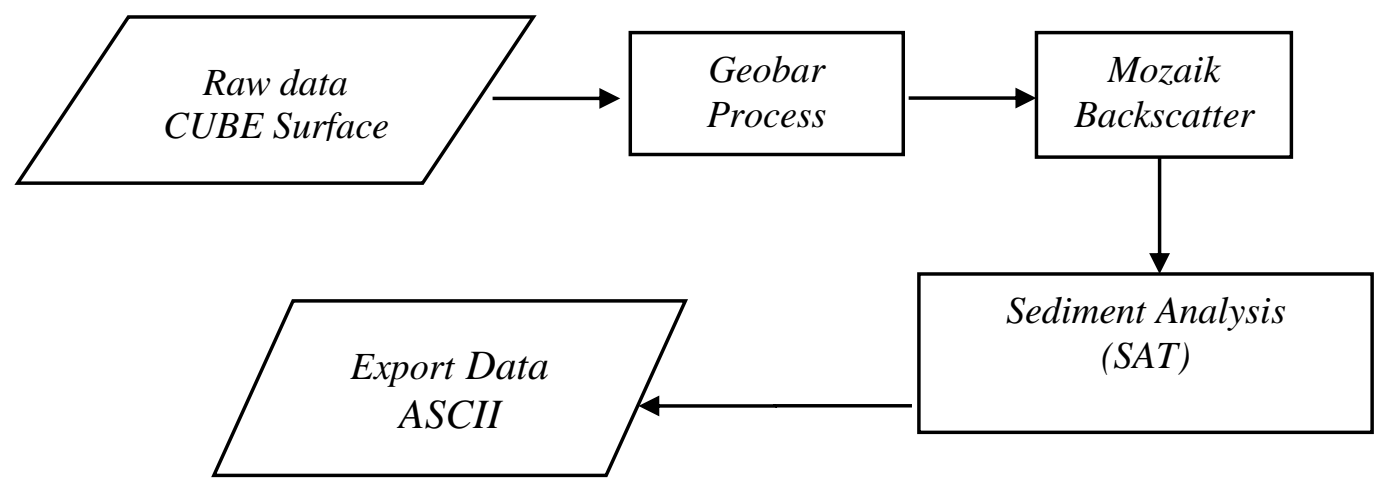

Figure 3. The backscattering data processing using ARA method.

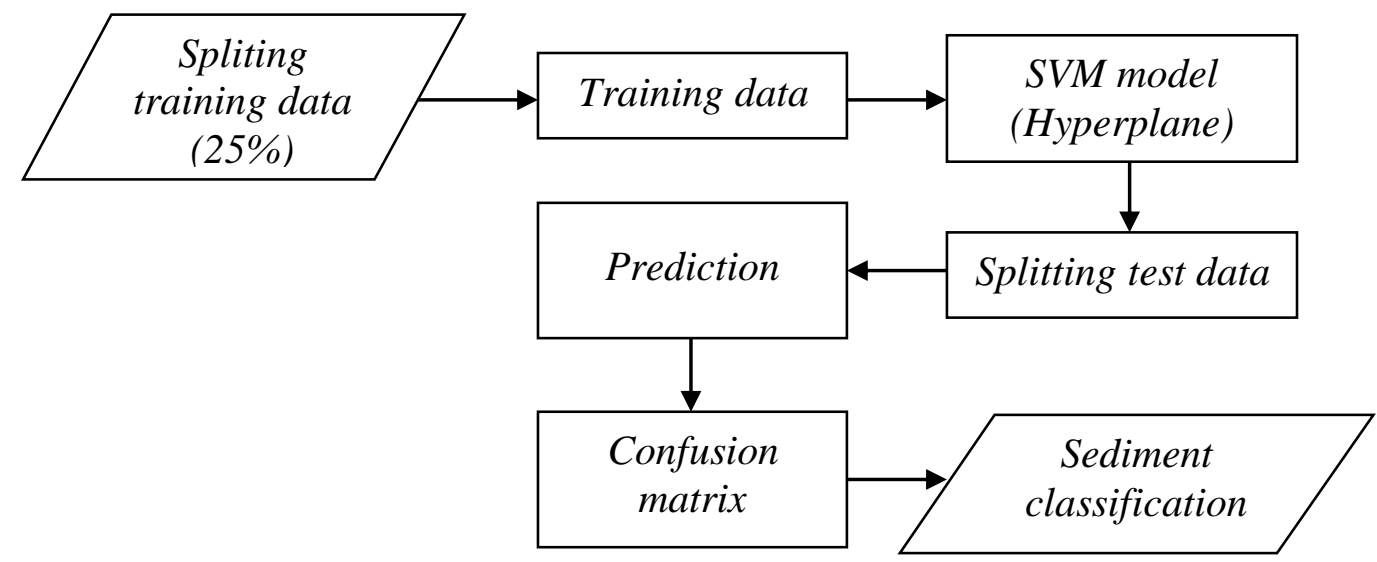

Figure 4. The backscattering data processing using SVM method.

kat lunak Python 3.8.2 dengan bantuan perangkat lunak Visual Studio Code untuk mempermudah visualisasi dan penggunaan perangkat lunak Python 3.8.2. Data yang perlu disiapkan untuk pengolahan berupa data hambur balik, lintang dan bujur dalam format file excel serta data sedimen hasil in situ. Data dibagi kedalam tiga tipe data, yaitu data training, data test dan data validation. Data training merupakan $25 \%$ dari data nilai 
hambur balik keseluruhan. Data test merupakan data keseluruhan nilai hambur balik di Teluk Palu setelah dikurangi dengan data training. Data validation merupakan data sedimen in situ yang digunakan untuk menilai akurasi dari model yang sudah dibentuk terhadap hasil klasifikasi sedimen dasar dengan menggunakan metode SVM.

\subsection{Uji Akurasi Cohen's Kappa}

Penggunaan uji akurasi Cohen's Kappa menurut Widhiarso (2006) digunakan untuk melihat tingkat kesepakatan antara dua rater terhadap setiap kategori yang diujikan pada kedua rater. Rumus untuk mencari kofiesien Cohen's Kappa menurut Widhiarso (2006) dituliskan sebagai berikut:

$K=\frac{P(a)-P(c)}{1-P(c)}$

Keterangan: $\mathrm{K}=$ koefisien Cohen's Kappa, $\mathrm{P}(\mathrm{a})=$ proporsi kesepakatan teramati, $\mathrm{P}(\mathrm{c})=$ proporsi kesepakatan harapan, 1= konstanta.

Landis \& Koch (1977) mengkategorikan nilai dari koefisien Cohen's Kappa dengan kategori sebagai berikut:

$\mathrm{K}<0.00=$ poor (buruk)

$0.00<\mathrm{K}<0.20=$ slight (sedikit buruk)

$0.21<\mathrm{K}<0.40=$ fair (cukup)

$0.41<\mathrm{K}<0.60=$ moderate (sedang)

$0.61<\mathrm{K}<0.80=$ substantial (baik)

$0.81<\mathrm{K}<1.00=$ almost perfect (sangat baik)

\subsection{Regresi Linier}

Kurniawan (2008) menyebutkan

bahwa regresi linier adalah metode statistika yang digunakan untuk membentuk hubungan antara satu atau lebih variabel bebas $X$ dengan sebuah variabel respons $Y$. Analisis regresi dengan satu variabel bebas $X$ disebut sebagai regresi linier sederhana. Model regresi linier menurut Draper \& Smith (1992) dinyatakan sebagai berikut:

$$
Y_{t}=\beta_{o}+\beta_{1} X_{i}+\varepsilon_{i}, i=1,2 \ldots, n
$$

Keterangan: $Y_{t}=$ Persamaan regresi linier, $\beta_{\circ} \& \beta_{1}=$ parameter regresi linier, $\varepsilon_{i},=$ konstanta.

\section{HASIL DAN PEMBAHASAN}

\subsection{Batimetri Teluk Palu}

Nilai Batimetri Teluk Palu dalam penelitian ini (Figure 5) didapatkan dari hasil pengolahan menggunakan perangkat lunak Caris 8.1, data batimetri ini sudah dikoreksi dengan menggunakan nilai pasang surut dan kecepatan suara yang diambil pada saat pemeruman menggunakan multibeam echosounder. Kecepatan suara di Teluk Palu relatif memiliki nilai yang sama yaitu sekitar $1540 \mathrm{~m} / \mathrm{s}$ mulai dari permukaan sampai dengan kedalaman $70 \mathrm{~m}$. Tipe pasang surut di Teluk Palu merupakan pasang surut campuran condong harian ganda dimana terjadi dua kali surut dan dua kali pasang dengan periode yang berbeda (Rahman et al., 2017).

Kedalaman yang terukur pada penelitian ini sangat bervariasi berkisar antara 10$1090 \mathrm{~m}$. Bagian Teluk yang paling dalam berada di tengah-tengah teluk bagian utara yaitu dengan kedalaman 800-1090 m, sedangkan untuk wilayah yang lebih landai berada di bagian tepian Teluk Palu dengan kedalaman berkisar antara 10-600 m. Kedalaman Teluk Palu bagian selatan cenderung lebih landai dibandingkan dengan kedalaman Teluk Palu bagian utara, sedangkan untuk bagian barat Teluk Palu lebih dalam dibandingkan dengan bagian timur Teluk Palu. Teluk palu memiliki kedalaman yang curam (Kusumatuti et al., 2018) seperti terlihat pada Figure 5, sehingga sangat mungkin terjadi longsor bawah laut apabila terjadi gempa. Kemungkinan terjadinya longsor bawah laut akan semakin besar apabila dasar perairannya berupa sedimen yang tidak solid seperti tipe sedimen pasir.

\subsection{Intensitas Hambur Balik Dasar Perairan}

Multibeam echosounder seperti yang telah dibahas sebelumnya, memiliki dua tipe 


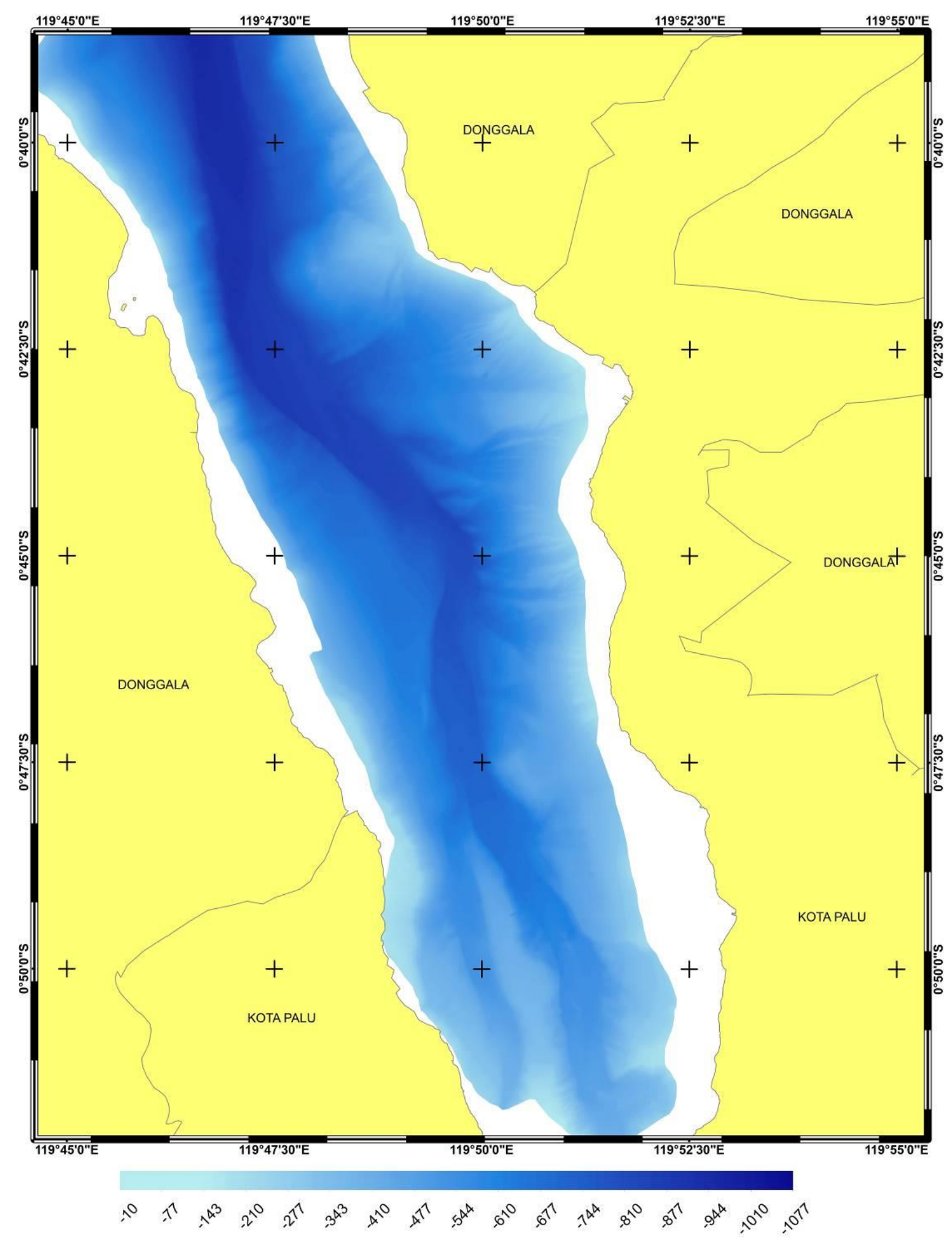

Figure 5. The bathymetry in gulf of Palu.

data yaitu data batimetri dan data intensitas hambur balik dari dasar perairan itu sendiri. Intensitas hambur balik ini dapat menun- jukkan keadaan dari sedimen dasar perairan, ketika dasar perairannya cenderung keras nilai hambur balik yang diterima akan 
memiliki nilai yang besar sedangkan untuk dasar perairan yang lebih lunak, nilainya akan lebih kecil. Manik (2015) menyatakan bahwa ukuran butiran substrat sangat memengaruhi nilai hambur balik dasar perairan, dimana semakin besar ukuran butiran maka semakin besar tingkat kekasaran dan kekerasan dari tipe substrat dasar perairan sehingga dapat menghasilkan nilai hambur balik yang lebih besar dari tipe substrat dengan ukuran butiran yang lebih kecil (Table 1). Intensitas hambur balik dituliskan dalam satuan decibel $(\mathrm{dB})$.

Intensitas dasar perairan dalam penelitian ini diolah menggunakan Caris 8.1 dengan melanjutkan pengolahan hasil CUBE dari batimetri untuk kemudian diproses menjadi mozaic backscatter, setelah terbentuk mozaic barulah bisa dilakukan ARA dan Seabed Analysis Tools (SAT) untuk klasifikasi tipe sedimen berdasarkan dari nilai hambur balik yang telah diperoleh.

Nilai intensitas hambur balik dasar perairan hasil pengukuran menggunakan multibeam echosounder Kongsberg EM 302 di Teluk Palu berkisar antara - $11 \mathrm{~dB}$ sampai dengan $-49 \mathrm{~dB}$. Klasifikasi tipe sedimen berdasarkan hasil intensitas hambur balik di Teluk Palu dapat dilihat pada Tabel 1. Hasil pengukuran intensitas hambur balik di Teluk Palu sebesar - $11 \mathrm{~dB}$ untuk tipe batuan berbentuk granul sedangkan untuk sedimen yang memiliki ukuran butir kecil seperti lempung memiliki hasil pengukuran nilai intensitas di Teluk Palu yang kecil yaitu sekitar $-49 \mathrm{~dB}$. Sedimen dengan ukuran butir yang besar akan memiliki nilai intensitas yang besar juga sedangkan untuk sedimen yang memiliki ukuran butir kecil akan menghasilkan nilai intensitas yang lebih kecil juga.

\subsection{Hubungan Intensitas Hambur Balik dengan Sudut Orientasi Target}

Nilai hambur balik selain dipengaruhi oleh tingkat kekerasan dasar perairan juga dipengaruhi oleh sudut orientasi target. Pada setiap jenis sedimen dengan sudut yang berbeda akan menghasilkan nilai hambur balik yang berbeda. Hal ini sesuai dengan

Table 1. Classification of sediment types based on backscattering values.

\begin{tabular}{|c|c|c|c|}
\hline Group & Sediment Type & $\begin{array}{l}\text { Backscattering } \\
\text { Intensity }(d B)\end{array}$ & $\begin{array}{c}\text { Backscatter Range } \\
(d B)\end{array}$ \\
\hline Rock & Granule & $-11 \mathrm{~s} / \mathrm{d}-13$ & $-11 \mathrm{~s} / \mathrm{d}-13$ \\
\hline \multirow[t]{8}{*}{ Sand } & Very Coarsed Sand & $-14 \mathrm{~s} / \mathrm{d}-15$ & \\
\hline & Coarsed Sand & $-15 \mathrm{~s} / \mathrm{d}-17$ & \\
\hline & Medium Sand & $-17 \mathrm{~s} / \mathrm{d}-19$ & \\
\hline & Fine Sand & $-19 \mathrm{~s} / \mathrm{d}-21$ & \\
\hline & Very Fine Sand & $-21 s / d-23$ & $-14 \mathrm{~s} / \mathrm{d}-29$ \\
\hline & Clayed Sand & $-23 \mathrm{~s} / \mathrm{d}-25$ & \\
\hline & Muddy Sand & $-25 s / d-27$ & \\
\hline & Silty Sand & $-27 \mathrm{~s} / \mathrm{d}-29$ & \\
\hline \multirow[t]{5}{*}{ Silt } & Coarsed Silt & $-30 s / d-31$ & \\
\hline & Medium Silt & $-31 s / d-33$ & \\
\hline & Fine Silt & $-33 s / d-35$ & $-30 \mathrm{~s} / \mathrm{d}-39$ \\
\hline & Very Fine Silt & $-35 s / d-37$ & \\
\hline & Sandy Silt & $-37 s / d-39$ & \\
\hline \multirow[t]{4}{*}{ Clay } & Clay & $-40 \mathrm{~s} / \mathrm{d}-41$ & \\
\hline & Sandy Clay & $-41 \mathrm{~s} / \mathrm{d}-43$ & \\
\hline & Silty Clay & $-43 \mathrm{~s} / \mathrm{d}-45$ & $-40 \mathrm{~s} / \mathrm{d}-49$ \\
\hline & Sandy Mud & $-45 s / d-49$ & \\
\hline
\end{tabular}


pendapat dari Fahrulian et al. (2018) yang menyatakan bahwa nilai hambur balik dasar perairan dipengaruhi oleh sudut orientasi target terhadap transducer yang dikenal dengan ARA dimana hambur balik dari bantuan kasar lebih tinggi dibandingkan lanau untuk sudut orientasi yang sama dan setiaptipe sedimen memberikan nilai hambur balik yang berbeda untuk setiap sudut yang berbeda.

Tiap sifat sedimen dapat memberikan pengaruh lebih banyak berdasarkan dari sudut datang (sudut orientasi), nilai hambur balik pada nadir akan lebih kuat disebabkan oleh kedataran permukaan sedimen sehingga memungkinkan sinyal akustik dapat direfleksikan lebih banyak ke transducer dengan sedikit sinyal akustik yang dihamburkan pada permukaan sedimen. Pada sudut datang kritis (semakin menjauh dari nadir), jumlah sinyal akustik yang dihamburkan akan lebih besar daripada sinyal akustik yang direfleksikan kembali ke transducer sehingga walaupun jenis sedimennnya sama, besar nilai intensitas yang diterima oleh transducer akan lebih kecil (Akbar et al., 2017). Gambaran mengenai hubungan antara intensitas hambur balik dengan sudut orientasi target pada penelitian ini dijelaskan oleh pernyataan diatas, bahwa perbedaan sudut orientasi target dapat memengaruhi nilai hambur balik setiap tipe sedimen, dimana untuk setiap sudut orientasi dan tipe sedimen yang berbeda akan menghasilkan nilai hambur balik yang berbeda pula (Figure 6).

Figure 6 memperlihatkan bahwa terdapat hubungan antara nilai hambur balik dengan sudut orientasi target, hubungan yang terbentuk adalah nilai hambur balik berbanding terbalik dengan sudut orientasi target. Semakin besar sudut orientasi target (menjauhi nadir) maka akan semakin kecil nilai hambur balik akustik pada setiap tipe sedimennya.

\subsection{Hubungan Intensitas Hambur Balik dengan Ukuran Butir}

Intensitas hambur balik juga dipengaruhi oleh ukuran butir sedimen. Stanic et al. (1989) menyatakan bahwa terdapat hubungan antara nilai hambur balik yang dihasilkan oleh sedimen kerikil, pasir, lempung dan lanau terhadap ukuran butiran. Hubungan antara nilai hambur balik dengan ukuran butir dapat dijelaskan sesuai grafik pada Figure 7.

Figure 7 dapat dilihat bahwa semakin besar ukuran butir maka semakin besar juga nilai hambur balik, baik pada data hasil pengolahan dengan menggunakan metode ARA pada Caris 8.1 maupun pada data yang didapat dari hasil pengambilan sedimen.

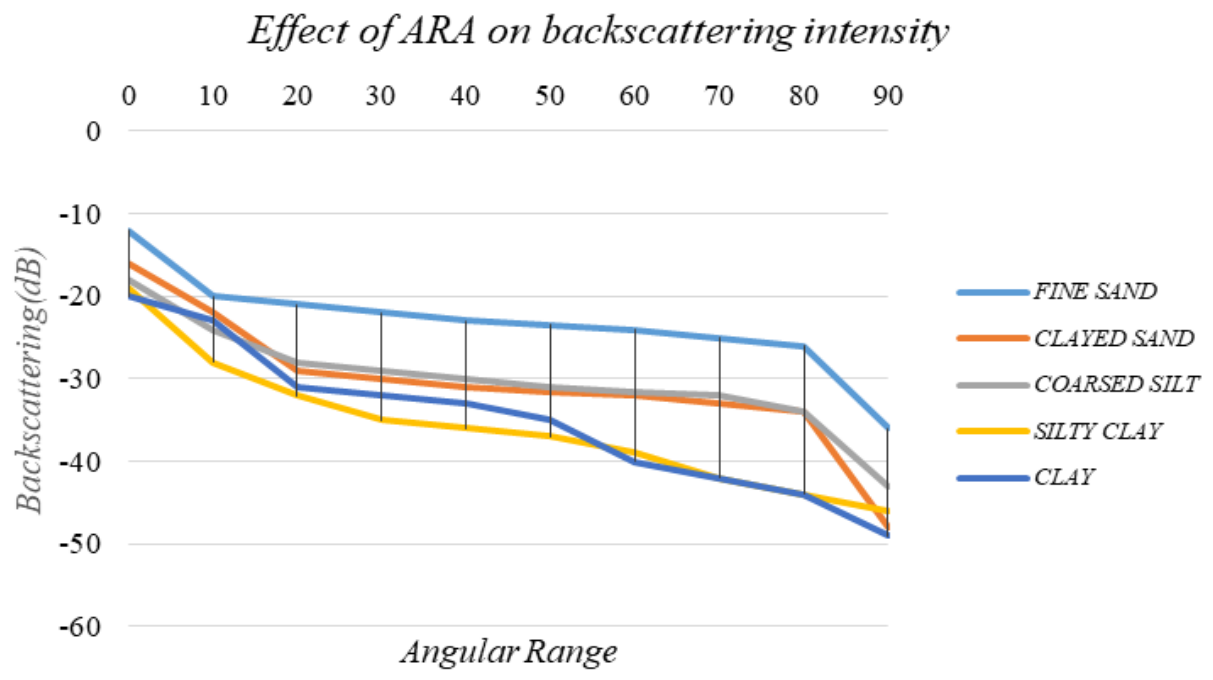

Figure 6. Relation of backscattering intensity with the target orientation angle. 


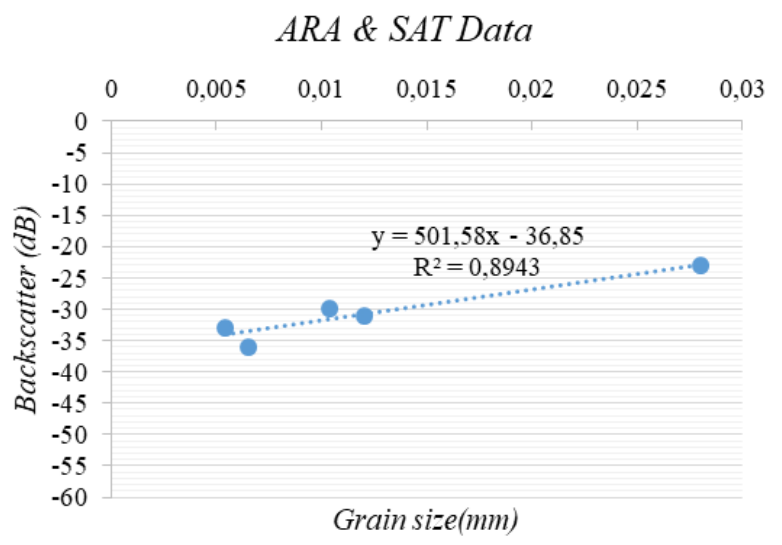

(a)

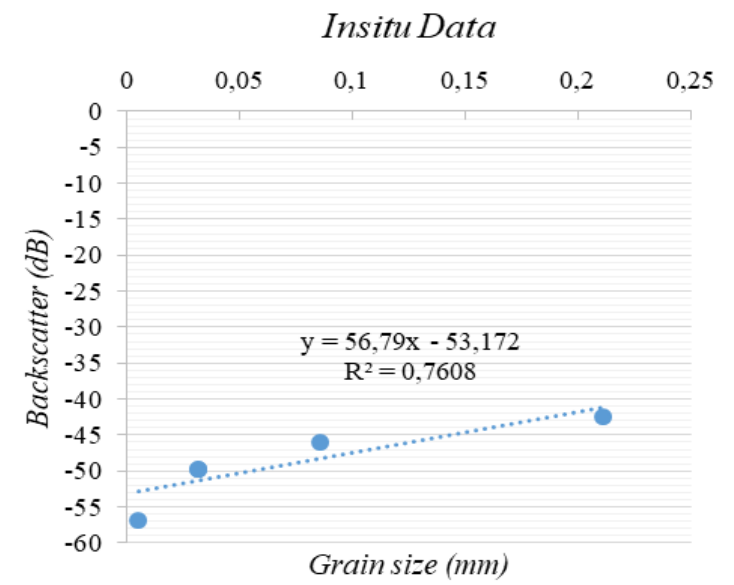

(b)

Figure 7. Relation of backscattering intensity with grain size (a) data by the ARA \& SAT method $(b)$ in situ gulf of Palu data.

Figure $8 a$ menunjukkan hubungan antara nilai hambur balik dengan ukuran butir yang dihasilkan dari ARA, dimana persamaan yang dihasilkan adalah $y=501,58 x-36,85$ dengan koefisien determinasi-nya sebesar 0,8943, dimana nilai $y$ merepresentasikan nilai hambur balik $(\mathrm{dB})$ dan nilai $x$ merepresentasikan ukuran butir (mm). Hasil koefisien determinasi dari Figure $7 a$ menunjukkan bahwa terdapat hubungan yang sangat kuat, hal ini ditunjukan dengan nilai koefisien determinasi > 0,75 (Sarwono, 2006).

Hubungan nilai hambur balik dengan ukuran butir in situ yang ditunjukan pada Figure $7 b$ menunjukkan koefisien determinasi yang kurang lebih sama besar dengan nilai koefisien determinasi pada Figure $7 a$ yaitu sebesar 0,7608 dengan persamaan yang dihasilkan adalah $y=56,79 x-53,172$. Koefisien determinasi yang dihasilkan pada data in situ lebih kecil jika dibandingkan dengan hasil koefisien determinasi pada data yang dihasilkan dari metode ARA, walaupun begitu hasil koefisien determinasi pada data in situ juga menunjukkan hubungan antara dua variabel yang sangat kuat (koefisien determinasi >0,75) sehingga dapat menjelaskan bahwa memang terdapat hubungan yang sangat kuat antara nilai hambur balik dengan ukuran butir. Hasil pada penelitian ini sejalan dengan hasil penelitian yang dilakukan oleh Pujiyati et al. (2010), Ningsih et al. (2013), Manik et al. (2015) dan Hamuna et al. (2018), terdapat korelasi positif antara kekuatan hambur balik dan ukuran butir sedimen.

\subsection{Klasifikasi Tipe Sedimen Berdasarkan Nilai Hambur Balik}

Klasifikasi sedimen secara konvensional biasanya dilakukan dengan pengambilan sampel sedimen secara in situ menggunakan grab sampler dan sampel sedimen kemudian diklasifikasi setelah dianalisis di Laboratorium menggunakan metode ayakan dan metode pipet, akan tetapi metode ini terbatas hanya pada perairan dangkal dan menengah saja, untuk perairan dalam dibutuhkan instrumen lain yang dapat menjangkau kedalaman sampai ribuan meter dari permukaan laut. Multibeam echosounder merupakan salah satu instrumen yang dapat dimanfaatkan untuk mendapatkan hasil klasifikasi sedimen dasar laut menggunakan nilai hambur balik. Nilai hambur balik dari multibeam dapat diproses dengan perangkat lunak tertentu sehingga didapatkan klasifikasi nilai hambur balik untuk setiap tipe sedimen.

Nilai Intensitas hambur balik pada penelitian ini memiliki nilai berkisar antara 11 sampai dengan -49 dengan jumlah data sebanyak 65536 data, dimana nilai intensitas hambur balik ini digunakan untuk klasifikasi tipe sedimen dasar di Teluk Palu. Hasil pe- 
ngolahan menggunakan SAT dan ARA menghasilkan rentang hambur balik untuk sedimen dasar di Teluk Palu seperti ditunjukan pada Table 1.

Hasil klasifikasi nilai hambur balik pada penelitian ini (Table 1) tidak berbeda jauh dengan hasil klasifikasi yang dilakukan oleh (Adi et al., 2016) yaitu nilai hambur balik untuk pasir halus $-17 \mathrm{~dB}$, pasir sangat halus sebesar $-20 \mathrm{~dB}$ dan lanau halus sebesar -25 dB. Hasil penelitian Manik (2006) menghasilkan nilai hambur balik untuk pasir sebesar - $18 \mathrm{~dB}$, lanau berpasir sebesar $-23 \mathrm{~dB}$ dan untuk lanau sebesar $-31 \mathrm{~dB}$. Adapun beberapa hasil penelitian mengenai nilai $\mathrm{SV}$ pasir dan lumpur antara lain, Akbar et al. (2013) mendapatkan hasil intensitas hambur balik untuk pasir sebesar - $20 \mathrm{~dB}$ dan lumpur 29 dB, dan Ningsih et al. (2013) mendapatkan nilai hambur balik untuk pasir sebesar $-13 \mathrm{~dB}$ dan lumpur $-31 \mathrm{~dB}$. Perbedaan nilai hambur balik akustik dasar perairan pada beberapa penelitian, selain disebabkan oleh kondisi perairan, dapat pula disebabkan karena penggunaan alat-alat dan frekuensi yang berbeda (Hamuna et al., 2018).

Klasifikasi diatas didasarkan dari hasil pengolahan dengan menggunakan metode ARA pada Caris 8.1. Rentang intensitas hambur balik untuk 4 kelompok besar sedimen yaitu batu, pasir, lanau dan lempung ditunjukan pada Table 1. Nilai hambur balik untuk batu berkisar antara -11 sampai dengan -13 dB sedangkan untuk pasir berkisar antara -14 sampai dengan -29 dB, lanau memiliki nilai hambur balik antara -30 sampai dengan -39 dB dan lempung memiliki nilai hambur balik antara -40 sampai dengan $-49 \mathrm{~dB}$. Hasil ini sejalan dengan hasil penelitian Manik et al. (2015) bahwa semakin besar ukuran butir maka semakin besar juga nilai hambur baliknya begitupun semakin kecil ukuran butir maka memiliki nilai hambur balik yang semakin kecil. Sedimen dasar yang diambil secara in situ sebanyak 10 titik ditampilkan pada Table 2, dan histogram data in situ ditunjukan oleh Figure 8.

Pada Figure 9, terlihat sedimen dasar dari Teluk Palu didominasi oleh pasir dan lanau. Wilayah yang memiliki tipe sedimen pasir yang besar terdapat pada wilayah yang berada di tepian baik tepi Barat maupun tepi Timur Teluk Palu, sedangkan untuk wilayah yang memiliki sedimen berupa lanau cenderung berada di tengah Teluk Palu. Hasil ini sejalan dengan penelitian Paundanan et al. (2015) yang menyatakan bahwa jenis sedimen di Teluk Palu dominan berpasir. Wilayah yang memiliki tipe dasar sedimennya berupa batu dan lempung tidak terlalu terlihat pada peta di atas karena luasnya yang sangat kecil jika dibandingkan dengan luas dari wilayah yang memiliki sedimen pasir ataupun lanau.

Table 2. The sediment taken in-situ.

\begin{tabular}{cccc}
\hline No & Position & Depth $(m)$ & In-situ Sediment Type \\
\hline 1 & $119^{\circ} 48^{\prime} 1.98^{\prime \prime}$ BT $0^{\circ} 38^{\prime} 2.03^{\prime \prime}$ LS & 29.5 & Gravely Sand \\
2 & $119^{\circ} 48^{\prime} 7.99^{\prime \prime}$ BT $0^{\circ} 40^{\prime} 0.02^{\prime \prime ~ L S}$ & 28.5 & Sand \\
3 & $119^{\circ} 51^{\prime} 3.98^{\prime \prime} \mathrm{BT} 0^{\circ} 43^{\prime} 0.03^{\prime \prime} \mathrm{LS}$ & 16.5 & Silt \\
4 & $119^{\circ} 51^{\prime} 5.97^{\prime \prime} \mathrm{BT} 0^{\circ} 45^{\prime} 4.03^{\prime \prime} \mathrm{LS}$ & 20.5 & Sandy Silt \\
5 & $119^{\circ} 51^{\prime} 59.99^{\prime \prime} \mathrm{BT} 0^{\circ} 48^{\prime} 0.01^{\prime \prime} \mathrm{LS}$ & 18.5 & Rock \\
6 & $119^{\circ} 52^{\prime} 5.99^{\prime \prime} \mathrm{BT} 0^{\circ} 50^{\prime} 0.01^{\prime \prime} \mathrm{LS}$ & 17 & Sandy Silt \\
7 & $119^{\circ} 52^{\prime} 3.97^{\prime \prime} \mathrm{BT} 0^{\circ} 51^{\prime} 8.03^{\prime \prime} \mathrm{LS}$ & 3 & Rock \\
8 & $119^{\circ} 51^{\prime} 59.98^{\prime \prime} \mathrm{BT} 0^{\circ} 53^{\prime} 0.03^{\prime \prime} \mathrm{LS}$ & 4 & Sandy Silt \\
9 & $119^{\circ} 49^{\prime} 59.98^{\prime \prime} \mathrm{BT} 0^{\circ} 52^{\prime} 1.01^{\prime \prime} \mathrm{LS}$ & 13 & Silty Sand \\
10 & $119^{\circ} 44^{\prime} 59.97^{\prime \prime} \mathrm{BT} 0^{\circ} 40^{\prime} 0.02^{\prime \prime} \mathrm{LS}$ & 33 & Rock \\
\hline
\end{tabular}

Source: PUSHIDROSAL 


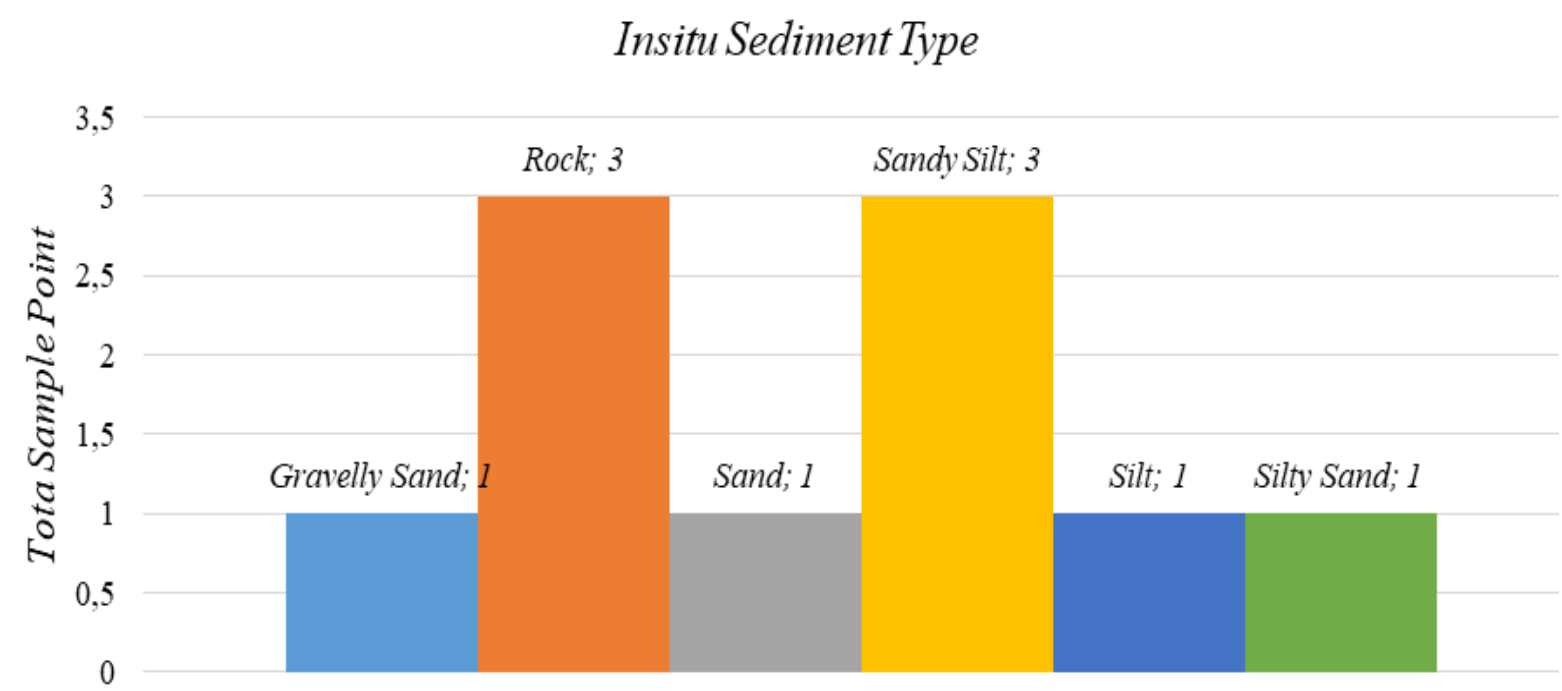

Figure 8. The histogram of in situ sediment.

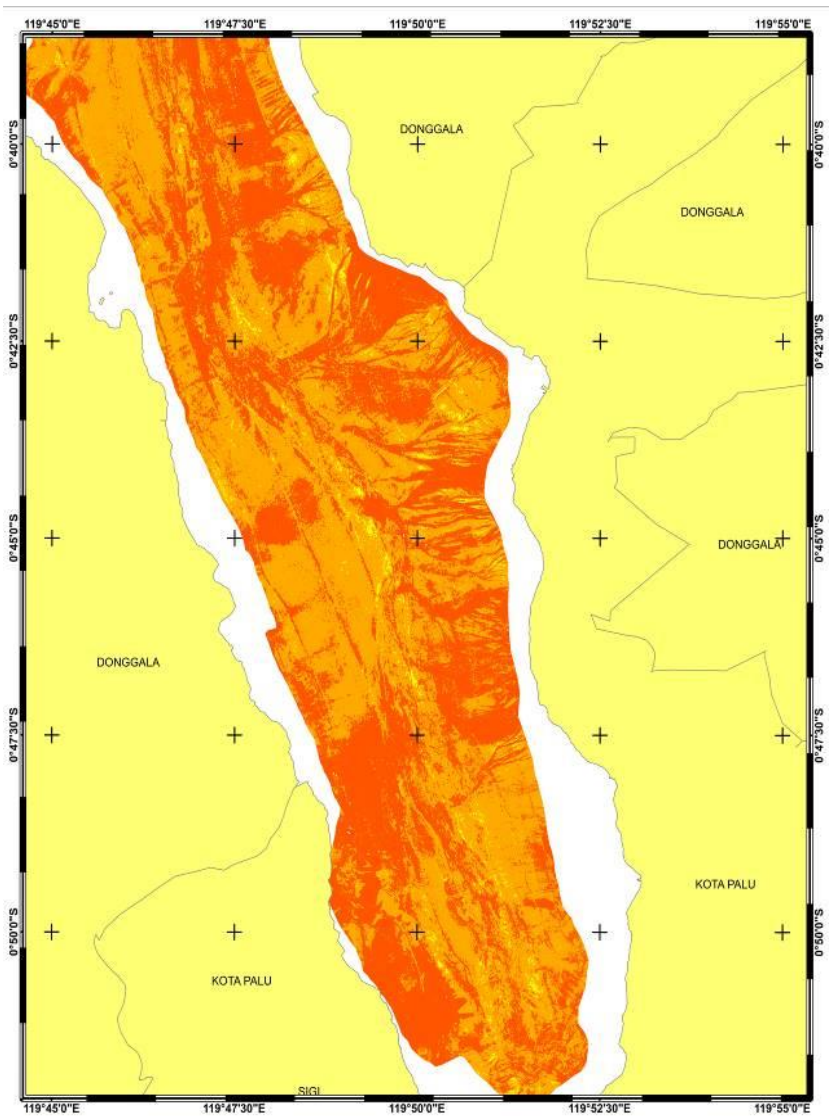

(a)

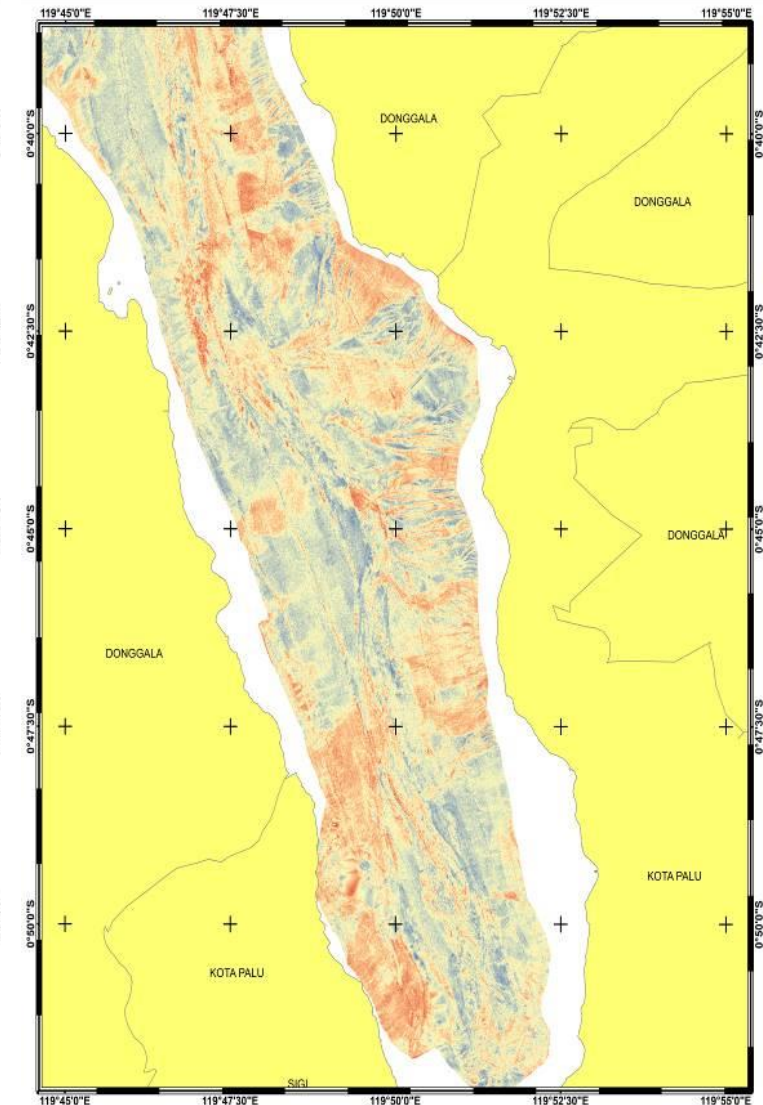

(b)

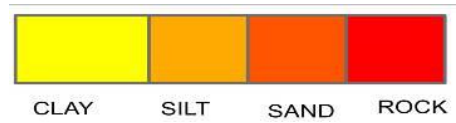

Figure 9. Distribution of Palu gulf sediments using ARA method (a) sediment distribution for 18 types of sediment (b) Sediment distribution for 4 large groups of sediments 


\subsection{Sebaran Sedimen Dasar \\ Teluk Palu Metode SVM}

Peta sebaran sedimen dasar Teluk Palu dengan metode SVM (Figure 10) menunjukkan sebaran dari enam tipe sedimen di Teluk Palu yaitu batu, pasir berkerikil, pasir, lanau berpasir, lanau dan pasir berlanau.

Peta sebaran sedimen menggunakan metode SVM diatas terlihat bahwa sedimen dasar dari Teluk Palu didominasi oleh pasir berlanau, lanau dan pasir dimana wilayah yang memiliki tipe sedimen pasir terdapat pada wilayah yang berada di tepian Teluk Palu yang dimungkinkan karena sedimen pasir terbawa oleh aliran sungai dan diendapkan pada muara sungai yang ada di tepian Teluk Palu. Wilayah yang memiliki sedimen berupa lanau maupun pasir berlanau cenderung berada di tengah Teluk Palu, hal ini dimungkinkan karena sedimen oleh gelombang dan terbawa oleh arus ke bagian tengah Teluk Palu.

Hasil penelitian sebaran sedimen, baik menggunakan metode ARA maupun menggunakan metode SVM menghasilkan peta sebaran sedimen dominan yang hampir sama yaitu dominan pasir dan lanau. Per- bedaan yang ada adalah terdapat sedimen dominan pasir berlanau pada sebaran sedimen menggunakan SVM, pasir berlanau merupakan sedimen campuran dari pasir dan lanau.

\subsection{Uji Akurasi dan Cohen's Kappa untuk Klasifikasi Sedimen di Teluk Palu}

Uji akurasi untuk sebaran sedimen dasar Teluk Palu dengan metode ARA dapat dilihat pada Table 3, sedangkan uji akurasi dengan metode SVM dapat dilihat pada Table 4. Uji akurasi ini dilakukan dengan membandingkan hasil klasifikasi dari data lapangan pada setiap titik sampel dengan masing-masing metode menggunakan koefisien kappa.

Hasil uji akurasi untuk metode ARA (Table 3) menghasilkan overall accuracy sebesar 50\% dan koefisien kappa dengan nilai 0,39. Landis \& Koch (1977) menyatakan bahwa nilai koefisien kappa 0,39 termasuk kedalam kategori cukup baik, sehingga klasifikasi menggunakan metode ARA cukup baik untuk merepresentasikan sebaran sedimen berdasarkan intensitas hambur balik akustik di Teluk Palu.

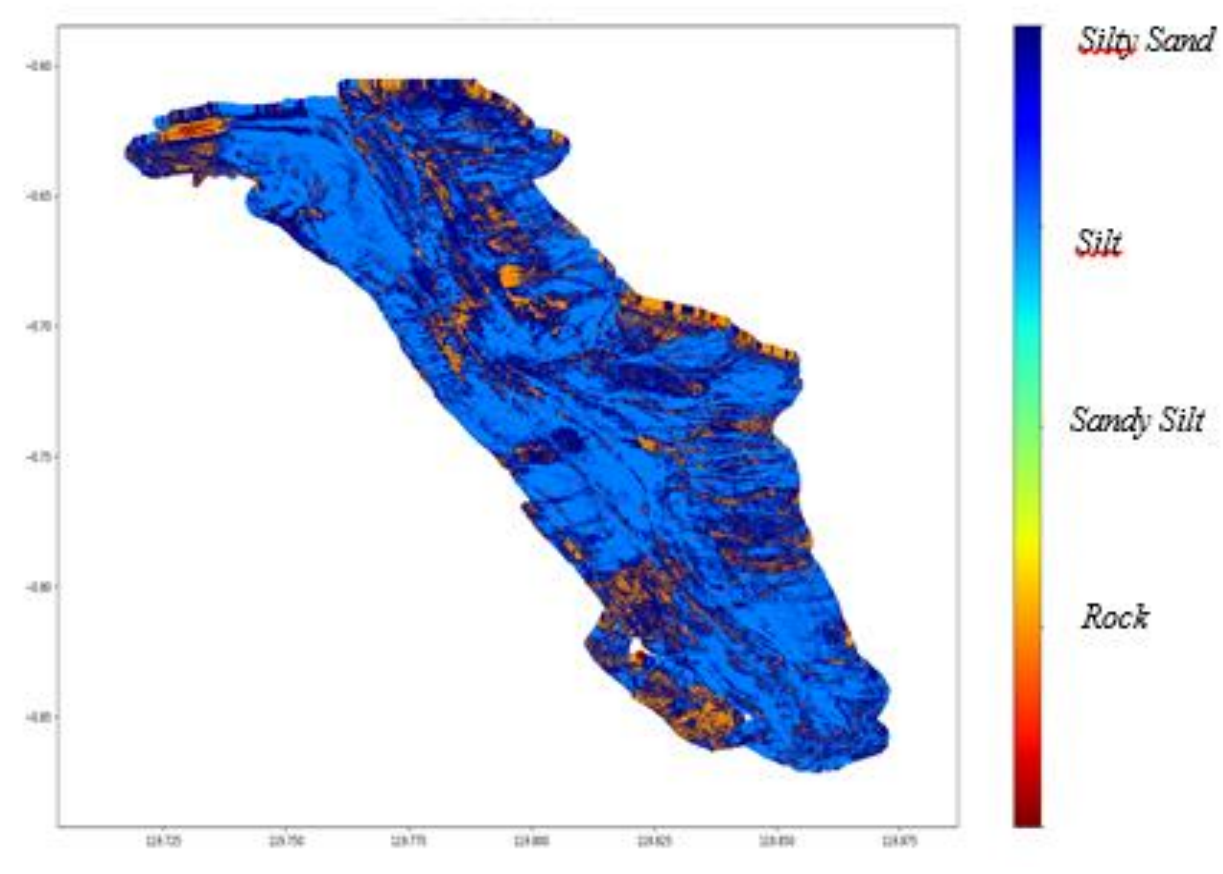

Figure 10. Distribution of Palu gulf sediments using SVM method. 
Table 3. The ARA method accuracy test.

\begin{tabular}{lccccccc}
\hline & $\begin{array}{c}\text { Gravelly } \\
\text { Sand }\end{array}$ & Rock & Sand & $\begin{array}{c}\text { Sandy } \\
\text { Silt }\end{array}$ & Silt & $\begin{array}{c}\text { Silty } \\
\text { Sand }\end{array}$ & Total \\
\hline Gravelly Sand & 0 & 0 & 0 & 1 & 0 & 0 & 1 \\
Rock & 0 & 2 & 1 & 0 & 0 & 0 & 3 \\
Sand & 0 & 0 & 1 & 0 & 0 & 0 & 1 \\
Sandy Silt & 0 & 0 & 2 & 1 & 0 & 0 & 3 \\
Silt & 0 & 0 & 0 & 0 & 0 & 1 & 1 \\
Silty Sand & 0 & 0 & 0 & 0 & 0 & 1 & 1 \\
Total & 0 & 2 & 4 & 2 & 0 & 2 & 10 \\
\hline Kappa Coeffisient & & & & & & & 0.39 \\
Overall Accuracy & & & & & & & $50 \%$ \\
\hline
\end{tabular}

Table 4. The SVM method accuracy test.

\begin{tabular}{lccccccc}
\hline & $\begin{array}{c}\text { Gravelly } \\
\text { Sand }\end{array}$ & Rock & Sand & $\begin{array}{c}\text { Sandy } \\
\text { Silt }\end{array}$ & Silt & $\begin{array}{c}\text { Silty } \\
\text { Sand }\end{array}$ & Total \\
\hline Gravelly Sand & 0 & 0 & 1 & 0 & 0 & 0 & 1 \\
Rock & 0 & 3 & 0 & 0 & 0 & 0 & 3 \\
Sand & 0 & 0 & 1 & 0 & 0 & 0 & 1 \\
Sandy Silt & 0 & 0 & 0 & 0 & 3 & 0 & 3 \\
Silt & 0 & 0 & 0 & 0 & 1 & 0 & 1 \\
Silty Sand & 0 & 0 & 0 & 0 & 0 & 1 & 1 \\
Total & 0 & 3 & 2 & 0 & 4 & 1 & 10 \\
\hline Kappa Coeffisient & & & & & & & 0.52 \\
Overall Accuracy & & & & & & & $60 \%$ \\
\hline
\end{tabular}

Hasil uji akurasi untuk metode SVM menghasilkan overall accuracy dengan nilai $60 \%$ (Table 4) dan koefisien kappa dengan nilai 0,52 (Table 4) yang termasuk ke dalam kategori sedang (moderate) menurut Landis \& Koch (1977). Klasifikasi menggunakan metode SVM memiliki nilai overall accuracy yang lebih tinggi daripada hasil klasifikasi menggunakan metode ARA.

\section{KESIMPULAN}

Penelitian ini didapatkan kisaran nilai hambur balik dari -11 dB sampai dengan -49 $\mathrm{dB}$ dimana dari nilai hambur balik ini didapatkan klasifikasi berupa 18 tipe sedimen yang dikelompokan lagi menjadi 4 tipe sedimen yaitu rock berkisar antara -11 sampai dengan $-13 \mathrm{~dB}$ sedangkan untuk sand berkisar antara -14 sampai dengan $-29 \mathrm{~dB}$, silt memiliki nilai hambur balik antara -30 sampai dengan -39 dB dan clay memiliki nilai hambur balik antara -40 sampai dengan -49 dB. Metode SVM terbukti berhasil mengklasifikasi tipe sedimen berdasarkan nilai intensitas hambur balik akustik di Teluk Palu dengan overall accuracy sebesar $60 \%$ dan nilai koefisien kappa sebesar 0,52 yang menunjukkan bahwa metode SVM merupakan metode klasifikasi dengan katergori sedang (moderate). Sedimen dasar Teluk Palu didominasi oleh tipe sedimen pasir berlanau, lanau dan pasir.

\section{UCAPAN TERIMAKASIH}

Kami mengucapkan terimakasih kepada semua pihak yang telah berkontribusi dalam penulisan ini, khususnya kepada pimpinan dan para staf Pusat Hidrografi dan 
Oseanografi TNI-AL (PUSHIDROSAL) atas bantuan dan kerjasamanya, sehingga penelitian dan penulisan artikel ini dapat terselesaikan dengan baik.

\section{DAFTAR PUSTAKA}

Adi, A.P., H.M. Manik, \& S. Pujiyati. 2016. Integrasi data multibeam batimetri dan mosaik backscatter untuk klasifikasi tipe sedimen (data integration bathymetry multibeam and backscatter mosaic for classification type of sedimen). J. Teknologi Perikanan dan Kelautan, 7(1): 77-84. https://doi.org/10.24319/jtpk.7.77-84

Akbar, H., S. Pujiyati, \& M. Natsir. 2013. Hubungan tipe dasar perairan dengan distribusi ikan demersal di perairan Pangkajene Sulawesi Selatan. $J$. Teknologi Perikanan dan Kelautan, 4(1): 31-39. https://doi.org/10.24319/jtpk.4.31-39

Akbar, K., D.G. Pratomo, \& Khomsin. 2017. Analisis nilai hambur balik sedimen permukaan dasar perairan menggunakan data multibeam echosounder EM302. J. Teknik ITS, 6(2): 154-157. https://doi.org/10.12962/j23373539.v $6 \mathrm{i} 2.24415$

Bishop, C.M. 2006. Pattern recognition and machine learning. Springer science and business media. Singapore. $738 \mathrm{p}$

Draper, N. dan H. Smith. 1992. Analisis regresi terapan. Gramedia. Jakarta. $671 \mathrm{p}$.

Debese, N., R. Moitié, \& N. Seube. 2012. Multibeam echosounder data cleaning through a hierarchic adaptive and robust local surfacing. J. Computer and Geoscience, 46: 330-339. https://doi.org/10.1016/j.cageo.2012.0 1.012

Fahrulian, H.M. Manik, \& H. Djoko. 2013. Dimensi gunung bawah laut dengan menggunakan multibeam echosounder di perairan Bengkulu. J. Ilmu dan Teknologi Kelautan Tropis, 5(1): 93-102.

https://doi.org/10.29244/jitkt.v5i1.775 4

Fonseca, L., C. Brown, B. Calder, L. Mayer, \& Y. Rzhanov. 2009. Angular range analysis of acoustic themes from stanton banks ireland: a link between visual interpretation and multibeam echosounder angular signatures. Applied Acoustics J., 70(10): 12981304.

https://doi.org/10.1016/j.apacoust.200 8.09.008

Fonseca, L. \& L.A. Mayer. 2007. Remote estimation of surficial seafloor properties through the application angular range analysis to multibeam sonar data. Marine Geophysical Research, 28: 119-126.

https://doi.org/10.1007/s11001.007.90 19.4

Gusman, A.R., P. Supendi, A.D. Nugraha, W. Power, H. Latief, H. Sunendar, S. Widiyantoro, Daryono, S.H. Wiyono, \& A. Hakim. 2019. Source model for the tsunami inside palu bay following the 2018 Palu earthquake, Indonesia. Geophysical Research Letters, 46(15): 8721-8730. https://doi.org/10.1029/2019GL08271 7

Hamuna, B., S. Pujiyati, N.M.N. Natih, \& L. Dimara. 2018. Analisis hambur balik akustik untuk klasifikasi dan pemetaan substrat dasar perairan di Teluk Yos Sudarso, Kota Jayapura. $J$. Ilmu dan Teknologi Kelautan Tropis, 10(2): 291-300. https://doi.org/10.29244/jitkt.v10i2.24 045

Hasan, R.C., D. Ierodiaconou, L. Laurenson, \& A. Schimel. 2014. Integrating multibeam backscatter angular responsse, mosaic and bathymetry data for benthic habitat mapping. PLOS One J., 9(5): 1-14. https://doi.org/10.1371/journal.pone.0 
097339

Kurniawan. 2008. R: a language and environment for statistical computing. $\mathrm{R}$ foundation for statistical computing. Austria. 257 p.

Kusumatuti, I.D., D. Anugrah, A. Listalatu, \& R. Farhan. 2018. Menata kembali pemukiman penduduk di sulawesi tengah dengan rencana terpadu. Badan pengembang infrastruktur wilayah (BPIW) kementerian PUPR. Jakarta. 73 p.

Landis, J.R. \& G.G. Koch. 1977. The measurement of observer agreement for categorical data. Biometrics, 33: 159-174. https://doi.org/10.2307/2529310

Ludtke, A., K. Jerosch, O. Herzog, \& Schluter. 2012. Development of a machine learning techniquw for automatic analysis of seafloor image data: case example, Pogonophora coverage at mud volcanoes. Computer and Geosciences J., 39: 120-128. https://doi.org/10.1016/j.cageo.2011.0 6.020

MacDonald, A. \& C. Collins. 2008. Taking geocoder to work. In: MacDonald, A. (ed). Proceedings of the Shallow Survey Conference 2008. Portsmouth. 1-9 pp.

Mandal, S., S. Rao, N. Harish, \& Lokesha. 2012. Damage level prediction of non-reshaped berm breakwater using ANN, SVM and ANFIS models. International J. Archit Oc Engineering, 4: 112-122. https://doi.org/10.2478/IJNAOE2013-0082

Manik, H.M. 2016. Acoustical measurement and biot model for coral reef detection and quantification. Advances in Acoustics and Vibration, 2016(235061511): 1-11. https://doi.org/10.1155/2016/2350615

Manik, H.M. 2015. Acoustic characterization of fish and seabed using underwater acoustic technology in Seribu Island
Indonesia. Marine Science Research \& Development J., 5(1): 1-9. https://doi.org/10.4172/21559910.1000157

Manik, H.M. 2012. Seabed identification and characterization using sonar. Advances in Acoustics and Vibration, 2012(532458): 1-5. https://doi.org/10.1155/2012/532458

Manik, H.M., M. Furusawa, \& K. Amakasu. 2006. Measurement of sea bottom surface backscattering strength by quantitative echo sounder. Fisheries Science J., 72(3): 503-512. https://doi.org/10.1111/j.14442906.2006.01178.x

Nasril, C.H. 2013. Kajian upaya peningkatan produksi bongkar muat di pelabuhan pantoloan dalam rangka menekan lama kapal di tambatan. Warta Penelitian Perhubungan, 25(5): 328336. https://doi.org/10.25104/w

Ningsih, E.N., F. Supriyadi, \& S. Nurdawati. 2013. Pengukuran dan analisis nilai hambur balik akustik untuk klasifikasi dasar perairan Delta Mahakam. $J$. Penelitian Perikanan Indonesia, 19(3): 139-146. https://doi.org/10.15578/jppi.19.3.201 3.139-146

Park, Y., S. Lee, \& S. Jung. 2011. Characterization of backscattering signal of $300 \mathrm{kHz}$ multibeam echo sounder. Proceeding of Symposium on Ultrasonic Electronics, 32: 289290.

Paundanan, M., E. Riani, \& S. Anwar. 2015. Kontaminasi logam berat merkuri $(\mathrm{Hg})$ dan timbal $(\mathrm{Pb})$ pada air, sedimen dan ikan selar tetengkek (Megalaspis cordyta) di Teluk Palu, Sulawesi Tengah. J. Pengelolaan Sumberdaya Alam dan Lingkungan, 5(2): 161-168. https://doi.org/10.19081/jps1.5.2.161

Pujiyati, S., S. Hartati, \& W. Priyono. 2010. Efek ukuran butiran, kekasaran, dan kekerasan dasar perairan terhadap 
nilai hambur balik hasil deteksi hydroakustik. J. Ilmu dan Teknologi Kelautan Tropis, 2(1): 59-67. https://doi.org/10.29244/jitkt.v2i1.786 3

Rahman, A., Arfiah, \& Y. Mudin. 2017. Model distribusi salinitas dan temperatur air laut dengan menggunakan metode numerik $2 \mathrm{D}$ di muara sungai toaya dan muara sungai palu. Gravitasi J., 16(2): 8-14.

https://doi.org/10.22487/gravitasi.v18 i2

Robotham, H., P. Bosch, J.C. GutiérrezEstrada, J. Castillo, \& I. PulidoCalvo. 2010. Acoustic identification of small pelagic fish species in Chile using support vector machines and neural networks. Fish Research J., 102: $115-122$.

https://doi.org/10.1016/j.fishres.2009. 10.015

Rzhanov, Y., L. Fonseca, \& L.A. Mayer. 2012. Construction of seafloor thematic maps from multibeam acoustic backscatter angular responsse data. J. Computer and Geoscience, 41: 181-187. https://doi.org/10.1016/j.cageo.2011.0
9.001

Sarwono, J. 2006. Metode penelitian kuantitatif dan kualitatif. Graha Ilmu. Yogyakarta. 286 p.

Shahua A. 2008. Introduction to machine learning. School of Computer Science and Engineering. The Hebrew University Press. Jerusalem. 148 p.

Schnare, T. 2014. Caris hips \& sips 8.0 manuals for hydrography and survey use. MGEO. Canada. 24 p.

Stanic, S., K.B. Briggs, P. Fleischer, W.B. Sawyer, \& R.I. Ray. 1989. High frequency acoustic backscattering from a coarse shell ocean bottom. $J$. of the Acoustical Society of America, 85(1): 125-136. https://doi.org/10.1121/1.397720

Vapnik, V. 1995. The nature of statistical learning theory. Springer-Verlag. New York. 299 p.

Widhiarso W. 2005. Mengestimasi reliabilita s. Fakultas Psikologi UGM. Yogyakarta. $30 \mathrm{p}$.

Received : 26 December 2019

Reviewed : 16 April 2020

Accepted : 13 August 2020 
